\title{
Economic development and colonias in Texas
}

\author{
C. Giusti \\ Department of Landscape Architecture and Urban Planning, \\ Texas A\&M University, USA
}

\begin{abstract}
This paper concentrates on economic, institutional, financial and legal matters that have a direct impact on sustainable planning and development. It reflects the research that is being developed in colonias on the Texas side of the US Mexico border region. Colonias in Texas are defined as areas with substandard housing, inadequate plumbing and sewage disposal systems, and low-income residents. Three case-studies are presented: the first refers to micro businesses and their potential to promote local economic development; the second is related to the "legalization" of "informal" developments; and the third refers to the sustainability of micro-credit for house improvement. Colonias, mainly isolated from urban areas, are starting to enjoy a relatively stable population, and regardless of the many difficulties they face, colonias are showing signs of being livable communities. This paper discusses these low-income communities from the point of view of promoting local economic and community sustainable development.
\end{abstract}

Keywords: economic development, micro credit, land tenure, housing.

\section{Introduction}

When approaching communities lagging economic dynamism, with no defined or stable institutions, with unclear legal framework, there is a concern on how sustainable are these communities. This paper will deal, specifically with three research projects in colonias along the Texas-Mexico border region related to their land, legal, and economic concerns. The first case study refers to a research done on the contribution of micro-businesses to local economies; the second one related to the effects of micro-credit for house improvements on the well-being con colonias; and the third one is related to a lot-titling regularization program and its effects on local residents. 
Colonias, distinct to most of the United States, resemble much of the characteristics of developing countries: institutional instability, uncertain legal regulations, low education levels, poor healthy and safety conditions, and so on. These are communities not only with low income population, but also with very minimal infrastructure and high levels of isolation. The purpose of this paper is to discuss ways to promote local economic development from different perspectives, and try to assert which programs may be suitable, in our quest for improving quality of life in a sustainable way. Specifically, the three casestudies point on issues related to housing, economic activity and land tenure and they will be discussed as they are related to sustainable local economic development.

The specific location of the colonias in our research is shown in Figure 1. The land and credit improvement studies were mainly made in Starr County, while the study on microbusinesses was done in Webb, Hidalgo and Cameron Park counties.

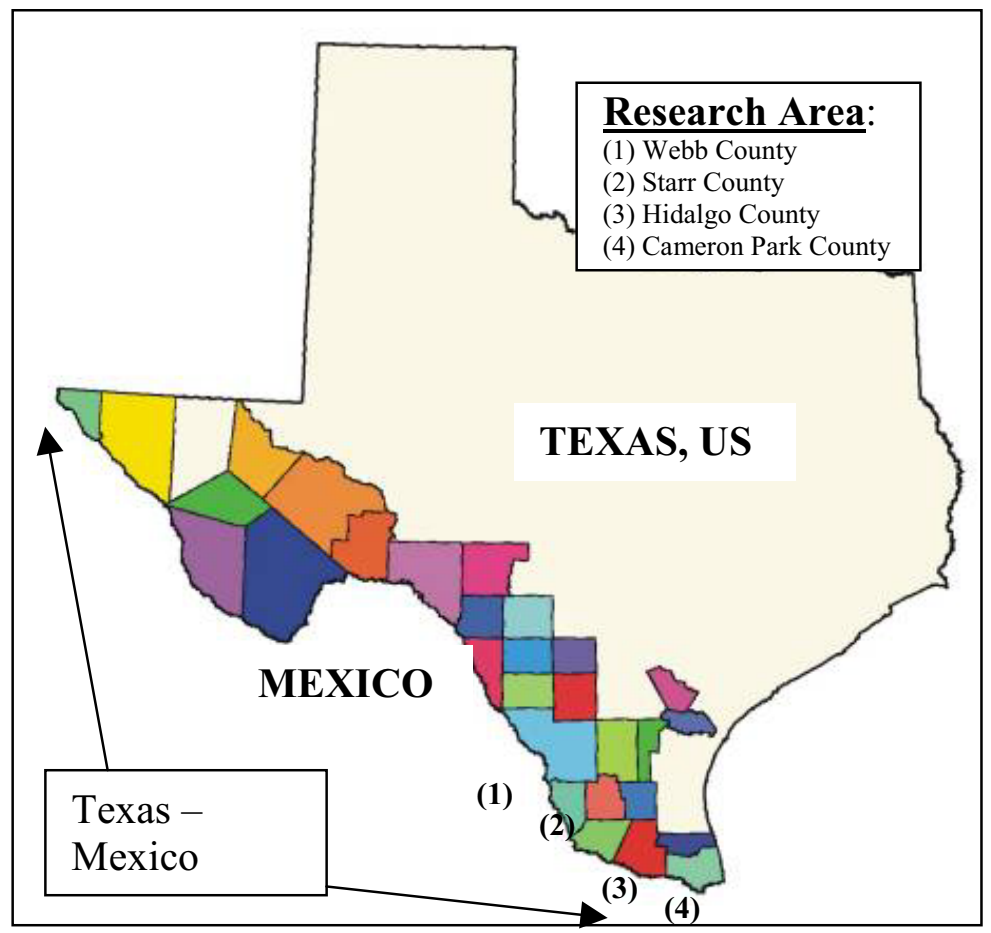

Figure 1: $\quad$ Map of Texas border counties and location of the case-studies.

Local economic development is defined, in this paper, as a process of creating assets to "generate improved and broadly shared economic well-being and quality of life for a community or region" [13]. Our approach is holistic, combining human, social and economic, legal and institutional aspects in the 
development process. The paper is organized as follows: first we present the main characteristics of colonias in Texas; then we present the three case-studies, and then we compare them and outline our conclusions as well as few policy suggestions.

\section{Colonias in Texas}

Following the Office of Attorney General definition, colonia in Texas refers to a residential area along the Texas-Mexico border that "may lack basic water and sewer systems, electricity, paved roads, and safe and sanitary housing" [11].

Table 1: $\quad$ Basic characteristics of colonias in Texas.

\begin{tabular}{|l|c|c|c|c|}
\hline & $\begin{array}{c}\text { Rio Bravo } \\
\text { Colonia }\end{array}$ & $\begin{array}{c}\text { Webb } \\
\text { County }\end{array}$ & Texas & US \\
\hline$\%$ Hispanic Pop. & $97.7 \%$ & $94.3 \%$ & $32.0 \%$ & $12.5 \%$ \\
\hline$\%$ High school graduate or higher/ $>25$ & $21.5 \%$ & $53.0 \%$ & $75.7 \%$ & $80.4 \%$ \\
\hline$\%$ Bachelor degree or higher/ $25>$ & $2.0 \%$ & $13.9 \%$ & $23.2 \%$ & $24.4 \%$ \\
\hline Same house 1995 & $70.3 \%$ & $58.8 \%$ & $49.6 \%$ & $54.0 \%$ \\
\hline Born in US & $60.3 \%$ & $69.7 \%$ & $85.0 \%$ & $87.7 \%$ \\
\hline Spanish at home & $95.3 \%$ & $91.3 \%$ & $27.0 \%$ & $10.7 \%$ \\
\hline Speak English less than "very well" & $58.2 \%$ & $44.2 \%$ & $12.3 \%$ & $5.2 \%$ \\
\hline$\%$ Unemployed & $6.9 \%$ & $4.9 \%$ & $3.8 \%$ & $3.7 \%$ \\
\hline$\%$ Of individuals below poverty level & $58 \%$ & $31 \%$ & $15 \%$ & $12 \%$ \\
\hline
\end{tabular}

Colonias can be found in the US-Mexico border counties of Texas, New Mexico, Arizona and California, but Texas has both the largest number of colonias and the largest colonia population.

According to the 2000 census, Texas contains 1,450 colonias, a 21.5 percent increase from 1,193 colonias recorded in 1992 that are located along the state's 1,248 miles border with Mexico. Currently, 350,000 residents (280,000 in 1992) are concentrated in these colonias, an increase of 25 percent in eight years.

The development of Texas colonias dates back to at least the 1950s, but the 1980s and early 1990s showed the largest growth. Developers, taking advantage of scarce housing resources, created unincorporated subdivisions using agriculturally worthless land, land that lay in floodplains, or other rural properties. They divided the land into small lots, put in little or no infrastructure, and then sold them to individuals seeking affordable housing. For a variety of reasons, regulations operating in most urban and rural developments in the U.S. were not mandatory, and colonia residents originally had very little control over the basic services provided to them or over their legal status as landowners $[8$, $18,20]$. Approximately half of the population in colonias does not have an adequate water supply and most do not have wastewater services. Most colonias 
have dirt roads without even gravel surfaces and have no surface drainage systems. Incidence of health problems is high.

Colonia residents are mainly of Hispanic/Mexican origin (97 percent, according to the latest census) [17]. Educational levels are very low in colonias. In Rio Bravo, one of the colonias studied, only 2 percent of the population has a bachelor's degree or higher. This is much lower than for Webb County at 14 percent, Texas at 23 percent, and the national rate of 24 percent. For illustration purposes table 1 shows some basic characteristics of one "typical" colonia compared with the rest of the county at the county, state and national levels.

Median annual household income in Rio Bravo is about one-third of the median household income in the U.S. and about a quarter of that in Texas. Average family size is 4.8 people, much higher than the 3.14 in the nation.

Nevertheless, despite all these problems, colonias show more stable population than other communities in the US. An interesting census variable is "residence in the last five years". Whereas in the U.S. as a nation, 54 percent of individuals have lived in the same house for the last five years, in the case of Rio Bravo colonia, more that 70 percent declare living in the same house for the last five years. This statistic tells us that population in colonias is more steady than in the rest of the country, contrary to the widely held belief that they are "temporary" communities. Colonias population is more established than anticipated. This is indeed, what we have observed in our case-studies and is presented next.

\section{Case-studies}

We will present next the summary of three case-studies related to three aspects of development: economic activity, housing, and land tenure. Each of them represents a variety of topics related to our holistic concept of local economic development in a sustainable way.

\subsection{Economic activity in colonias - Microbusinesses}

Colonias microenterprises will typically be family businesses with very few employees. A microbusiness is defined here as a business with less than 10 employees or a one-person only (also considered as self-employment). Furthermore, in our case we will also add a SBA [14, 15] definition of "disadvantage" entrepreneur: an owner who is denied access or has no access to credit due to his/her lack of income.

Colonias, against prior belief, enjoy a relatively stable population, and regardless of the many difficulties they face, are showing signs of being livable communities. As they are small and un-connected communities their provision of goods and services is limited. To cover these needs many businesses have been established even without financial support. Our observation in colonias show the existence of a variety of local shops and business of a wide range of 
scope: from basic plumbing and housing maintenance services to tax advise, beauty salons, day-care services, and most of anything, small restaurants and / or grocery stores.

Microbusiness, then, emerge to satisfy the needs of a growing (however small) and dynamic population. Additionally, most colonia resident have limited technical skills, lack of language and many of them have no English proficiency limiting their access to labor markets $[1,4,9]$. Self-employment and microbusiness become the alternative of low-income individuals who are in need of increasing family incomes.

Microbusiness owners and self-employment are very similar concepts in the context of colonias, and in many instances the concepts are used indistinctively. Self-employed men and women in colonias respond to two basic requirements: they serve a need from the community and they pursue their businesses as a means to surviving and as a complementary way to increase their family income.

\subsubsection{Financing microbusinesses}

The majority of business owners in colonias are out of the realm of formal banks and financial institutions. They concentrate in economic sectors that have easy access as they require limited initial investment, therefore the risk is minimized.

Most of the initial capital, as well as their working capital or improvements done, are financed with personal and / or family savings. Our research even shows that in most cases business owners decided not to apply for any loans. This is observed as the rate of loan approval of the few that actually apply is not that low. They self-exclude themselves from applying. Why?

We propose that business owners are rational economic agents, and as any other entrepreneur they maximize profits given particular restrictions: budget, knowledge, network, time, and human capital, we also propose that they minimize risk. Even in the cases they could receive loans, by not entering formal financing, business owners are minimizing the risk connected to such loans.

\subsubsection{Microbusiness and local development}

The contribution of microbusiness in colonias is more than just serving community needs in the form of goods and services [3, 12]. First of all, they allow local residents generate most-needed income. Second, we observed that many business owners pay some kind of taxes or fees. They are very small but still need to comply with basic regulations, especially those in the food or restaurant business - a large majority. Third, although not in big numbers, still they generate some level of employment. In general this is more part-time jobs, but is exactly the type of jobs that are capable of absorbing the type of labor available in colonias: low-skill, minority population in need for complementing family income $[6,7,16]$. Any local job creation results on more cash circulation within the community.

\subsection{Housing and land market in colonias}

Housing condition in colonias is poor. In imprecise lot plans and unclear legal regulations, houses have emerged without following any government control or 
regulation. As in many cases no basic infrastructure was available in colonias, many houses were build without water, wastewater or electricity. Even today not all houses have basic services. The majority of the housing stock, however, has improved since.

\subsubsection{Incremental construction}

It is common to find, as in developing countries, many self-built houses and very little or no-at-all government control to ensure minimum construction standards. As houses started with one or two rooms, with the passing of time and as income is available, they have expanded to accommodate the needs of growing families.

This practice, while common and many times encouraged in low-income neighbourhoods in developing countries, is not common in other parts of the US nowadays. Strict regulation in the construction industry is prevalent and safety and security controls are being tightly enforced in every new building in the US. Nevertheless this is prevalent in colonias.

\subsubsection{Financing and housing in colonias}

Once more we observed that also in the case of housing financial institutions have very little presence in colonias $[19,20]$. As local residents are low-income individuals with poor or inexistent financial history, very likely they will not be on the radar of local banks. The result has been a lack of access to financial credit by the majority of colonia residents who have built their basic houses and improvements, with their own limited personal and family savings.

One of the few institutions that actually lend money for this purpose in colonias is the Community Resources Group, a no-profit organization who has programs in several counties along the Texas border. They have implemented a micro-credit program assisting home-owners with their improvements. Current research on the benefits and/or problems of this program is undergoing by the author of this paper. Results of this research should be published at the end of this year. However, our initial perception is that very small loans have a dramatic impact on the well being of local residents. First of all, the small amount of the loan make it affordable within limited family budget; second these loans allow homeowners undertake works that are necessary to improve the quality of their houses; third, with that loan residents typically local labour (not only unpaid family members but also full time or part time jobs); fourth, they will also need to buy materials to do the improvement, and we observed that most of the supplies come from local vendors; fifth, as property values increase due to these loan, taxes on these properties increases. All these elements give a more comprehensive view of this program within these communities. A final observation on this microcredit program is that it seems that payment rates are not very different than in formal banks.

\subsection{Land tenure}

Colonia residents bought their lots through a contract for deed, a propertyfinancing method whereby developers typically offer a low down payment and low monthly payments but no title to the property until the final payment is 
made [8, 18]. Although this arrangement is very dubious, it has been an affordable alternative for thousands of families who could not afford formal financing systems [10]. Payment was often not a fixed amount and a common practice was that residents paid "as money was available."

The informal, unplanned way in which these communities emerge has been changing and improving since the late 1990s, partly due to deliberate policies enacted by the Texas legislature. Land title has been a key element in this reform. One of the immediate objectives of such legislation was the conversion from contract for deed to a more formal legal instrument called warranty deed. The objective was to reduce uncertainty and minimize tenure conflicts assigning legal ownership and responsibility for property taxes.

When analyzing the effects of such title program we found that most residents of colonias believed themselves to be "owners" of their lots even before receiving a deed. This is similar to what is reported happening in developing countries [5]. As long as they were making payments they had a "sense of ownership". This explains why residents in these colonias were making home improvements even without a proper legal deed on their properties. This perception, however, was not validated by the "legal" system.

An important consequence of lot ownership is the fact that the new lot owner must start paying taxes. It was observed that most of them are not reluctant to do so. As taxpayers, residents have changed their perception of their "right" to request basic infrastructure from local officials to improve the provision of services as water, sewage, paved roads. The fact of having legal also meant an "external" validation of their status as owners, and has also had an empowering effect as members of their communities.

In terms of market value, our research shows that in real terms the price per square foot has not changed significantly due to legal ownership. Getting proper title did not change market conditions and the isolation of colonias from main cities and their lack of basic services.

Another element that was also explored in our research was to what extent new owners were willing to use this new asset as a backup for entering the financial system. Much is being proposed in terms that "informal" occupation of land is equivalent to having useless assets. Because there is legal rights over the land they occupy residents cannot use this asset in the financial market [2]. Following this argument, residents were expected to use their new lot title as collateral for loans. However, this is not what we mainly observed. Few residents are currently using or expressed their intention of using their loans as collateral. In this case the explanation has two sides: from the "demand" point of view, in most cases new owners are very reluctant to jeopardize their only asset and do not want to risk losing it. From the supply point of view, financial institutions are not actively pursuing these "clients", as the status of new owners has not changed dramatically just by the fact of owning their land. They are still characterized as low-skilled workers who do not have stable and well-paid jobs. As the market value of these lots is not growing dramatically, it is not a "profitable" business for the banks to give loans to individuals who, in their observation, are still high-risk clients. 
Therefore this titling program is observed as positive in terms of enhancing quality of life in colonias, it has not resulted on a more active participation of the new owners in the financial market.

\section{Summary and discussion}

We have briefly presented three case-studies related to colonias during the last four years on three aspects of development: economic activity, housing, and land tenure. We introduced some of the many complex issues facing colonias: from the results of a titling program, to the existence of microbusiness, and the special characteristics of land and housing markets. Next we frame all these elements from the view of local economic and sustainable development.

First of all colonias are the result of "free" market forces without government controls. This particular outcome of supply and demand forces did not bring very positive results in terms of quality of life in these communities. And the data collected suggest the need for some type of intervention.

Second, colonia, are starting to enjoy a relatively stable population, and regardless of the many difficulties they face, colonias are showing signs of being livable communities. As dynamic communities, they are in constant need of more goods and services.

Third, colonia residents are rational agents subsisting within very limited budgets, a fragile built environment and unclear legal setting. We found sluggish land and housing markets where residents value their properties more for their use-value than their exchange-value. A house is the place to raise their families and they are not risking this valuable (in personal not in market terms) asset.

Fourth, colonias residents do pay taxes: both business and property taxes. On the one side this validates their ownership on their property and business; and on the other side, as tax payers, they can demand more services from local authorities.

Fifth, self-employed men and women in colonias respond to two basic requirements: on the one side they serve the growing needs for goods and services from the community; and on the other side they pursue their businesses as a means to surviving and as a complementary way to increase their family income.

Sixth, to promote local development it is not enough to secure property titles. This is a necessary but not sufficient condition. It is also essential to provide basic infrastructure like water, electricity, paved roads; a better education level, access to employment (through self-employment or jobs) and mainly access to credit.

Seventh, an urgent need in colonias is credit. As financial institutions are reluctant to give credit to low-income residents with unsecured jobs, it is necessary to delineate more creative ways to provide access to credit. We have briefly presented a successful case of microcredit for house improvement. Very small loans have many advantages: they are affordable and at the same time they have a broader impact in the community in terms of living conditions and 
community development. House improvements need labour and materials, and residents find them within their communities, contributing with the local economy. As they are rational agents we should expect that they will maximize the benefits of such loans and this will have positive direct impact in the quality of life in colonias.

Finally, financial credit for house improvements can be differentiated from business credit. In the first case it has an immediate impact on health, safety, and security of families. In the case of business loans the effects are more indirect, but it does not mean they are not important. We observed that these businesses make an important contribution to local economic development.

\section{References}

[1] Bates, T. Race, Self-Employment, and Upward Mobility: An Illusive American Dream. Washington, DC: The Woodrow Wilson Center Press, and Baltimore: John Hopkins University Press. 1997.

[2] De Soto, H. El misterio del capital: por qué el capitalismo triunfa en Occidente y fracasa en el resto del mundo. Lima: Empresa Editora El Comercio, 2000.

[3] Glazer, N. Affirmative Discrimination: Ethnic Inequality and Public Policy. New York: Basic Books. 1975.

[4] Glazer, N. \& Moynihan, D. Beyond the Melting Pot: The Negroes, Puerto Ricans, Jews, Italians, and Irish of New York City. Cambridge: M.I.T. Press. 1970.

[5] Hall, P. Microenterprise. World Watch 9 (March-April):10-19. 1996

[6] Harrison, R. Houston Hispanic Entrepreneurs: Profile and Needs Assessment. New York: Garland Publishing. 1995.

[7] Headd, B. The characteristics of small-business employees. Monthly Labor Review 123, 4: 13-18. 2000.

[8] Larson, J. Free markets in the heart of Texas. Georgetown Law Journal 84: 179-260. 1995.

[9] Light, I. \& Rosenstein, C. Race, Ethnicity, and Entrepreneurship in Urban America. New York: Aldine de Gruyter. 1995.

[10] Mettling, S. The Contract for Deed. Chicago: Real Estate Education Company. 1997.

[11] Office of the Attorney General of Texas (OAG). Texas and Mexico Border Issues. http://www.oag.state.tx.us/index.shtml 2006.

[12] Raheim, S. Microenterprise as an approach to promoting economic development in social work. International Development 39, 1: 69-82. 1996

[13] Seideman, K. Economic Development Finance. Sage publications: Thousand Oaks. 2001.

[14] Small Business Administration. Characteristics of small business employees and owners. SBA, Office of Advocacy. http://www.sba.gov/advo/stats/ch_em97.pdf, 1998. 
[15] Small Business Administration. Small business by the numbers. SBA, Office of Advocacy. http://www.sba.gov/advo/stats/sbfaq.pdf 2003

[16] Servon, L.\& Bates T. Microenterprise as an exit route from poverty: recommendations for programs and policy makers. U.S. Census Bureau, Center for Economic Studies, CES 98-17. Accessed through EconPapers. http://econpapers.hhs.se/paper/wopcenses/98-17.htm 1998

[17] U.S. Census Bureau. Census 2000. http://www.census.gov. 2002.

[18] Ward, P. Colonias and public policy in Texas and Mexico: urbanization by stealth. Austin, TX: University of Texas Press. 1999.

[19] Ward, P., De Souza, F., Giusti, C., Larson J., \& May, M. An evaluation of the Community Resources Group (CRG) colonia lot titling program in Rio Grande City, Starr County, Texas. Report presented to the CRG. 2003.

[20] Ward, P. De Souza, F., \& Giusti, C. (2004). 'Colonia' Land and Housing Market Performance, and the Impact of Lot Title Regularization in Texas. Urban Studies, 41 (13), 2621-2646. 